\title{
Perinatal management at the lower margin of viability
}

\author{
Janet M Rennie
}

\section{Definition}

Lord Donaldson defined viability as the point when a child can breathe either naturally or with the aid of a ventilator. ${ }^{1}$ Fetuses of 14 weeks gestation can be born with a heartbeat and may gasp, but cannot sustain life. Live birth is therefore an invalid indicator of viability. Viability is perhaps better defined as the ability both to live and to grow and develop 'normally'. ${ }^{2}$ Normality is a very imprecise term. Baby $\mathrm{K}$, an anencephalic, remains alive and is growing after several years on a ventilator, although she has not developed any skills at all. ${ }^{3}$ Most would agree that her existence is not worthwhile and her total lack of development renders her nonviable using the definition of Dunn and Stirrat. ${ }^{2}$ Even here, however, the hope of a miracle has persuaded the courts to order continuation of life sustaining treatment. Few cases are as clearcut as this and there is often conflict about the quality of life; the parents of Thomas Creedon felt that his lack of development was such that his life was not worth living, ${ }^{4}$ but it remains to be seen whether a British court would have sanctioned the withdrawal of his gastrostomy feeds.

In perinatology difficult quality of life judgments are common. A pure sanctity of life philosophy is not held by many parents, neonatologists, or nurses. Often this judgment involves a pregnancy which threatens to end very early. After 27 weeks gestation intact survival exceeds $50 \%$, whereas intact survival has been reported in only a few children delivered at 22 weeks. I will use the term marginal viability to refer to the period between $23^{+0}$ and $26^{+6}$ weeks of pregnancy. The live birth of such an infant occurs twice in every thousand deliveries. This neonatal emergency is therefore about as common as the birth of a severely asphyxiated infant at term. The prognosis for the group as a whole is similar to that of severe hypoxic ischaemic encephalopathy, in that $50 \%$ of the babies die and $50 \%$ of the survivors are handicapped. There is often some warning, however, of very preterm birth and this allows for planning regarding the place and mode of delivery, and time for consultation with the parents. In this review I aim to provide some guidance which the reader can adapt to develop a local protocol. Midwives and junior doctors particularly welcome clear written guidelines in this difficult area, although further senior input is obviously essential at the time.

\section{Immediate management of threatened delivery at 23-26 weeks of gestation}

The management of a mother who is threatening to deliver during this period should initially involve every effort to delay the birth. The chance of survival improves by $2 \%$ a day during this period of gestation. Consideration should be given to transfer to a perinatal centre with experience in the care of very premature infants, so that the pregnancy can be managed by an obstetrician with a perinatal interest and an experienced neonatologist. Their attitude to antenatal steroids, mode of delivery, tocolysis and intrapartum antibiotics may be more aggressive because of a wider experience, and this may partly explain the variation in outcome seen between centres. Experience is also valuable in knowing when to stop. Milligan found a noticeable difference in outcome within a single centre according to whether or not the obstetrician adopted a passive or active attitude. ${ }^{5}$ Antenatal steroids should be used as there is evidence that they are effective in this group. There is no evidence that caesarean section confers benefit, although analysis of the published work is difficult because large numbers of deliveries are carried out this way. A team approach to perinatal management is vital and requires leadership. Failure of communication at the top can lead to paradoxes such as an inexperienced or unavailable neonatologist when the obstetricians have just carried out a caesarean section purely for fetal reasons, or the delivery of a bruised, acidotic, immature fetus after a prolonged unmonitored labour with untreated maternal chorioamnionitis, whose parents are anticipating a good outcome from neonatal intensive care.

\section{Prenatal counselling for parents}

There are those who take the view that the prognosis is improving so fast that it is impossible to give an accurate picture to parents whose baby is about to deliver at 23-26 weeks of gestation, pointing out that only recently 28 weeks was considered the limit of viability. A trend to improved outcome has certainly been reported by several authors reporting results 
Table 1 Summary of published data reporting survival by gestational age, babies born 1977-93

\begin{tabular}{|c|c|c|c|c|c|c|}
\hline \multirow[b]{2}{*}{ Place } & \multirow{2}{*}{$\begin{array}{l}\text { Year of } \\
\text { birth }\end{array}$} & \multicolumn{4}{|l|}{ Gestational age (weeks) } & \multirow[b]{2}{*}{ Reference } \\
\hline & & 23 & 24 & 25 & 26 & \\
\hline $\begin{array}{l}\text { Royal Women's, Melbourne, } \\
\text { Australia } \\
\text { Queen's, Melbourne, Australia } \\
\text { Ontario, Canada } \\
\text { Novia Scotia, Canada } \\
\text { Liverpool, UK }\end{array}$ & $\begin{array}{l}1977-82 \\
1977-84 \\
1979-82 \\
1980-82 \\
1982-93\end{array}$ & $\begin{array}{l}2 / 287 \%(0-23) \\
1 / 714 \%(0-58) \\
0 / 70 \%(0-41) \\
7 / 2726 \%(11-46)\end{array}$ & $\begin{array}{c}2 / 277 \%(1-24) \\
13 / 4032 \%(19-49) \\
9 / 2339 \%(19-61) \\
1 / 1010 \%(0-44) \\
30 / 8436 \%(25-47)\end{array}$ & $\begin{array}{c}11 / 5420 \%(10-33) \\
11 / 4425 \%(13-40) \\
28 / 4467 \%(48-78) \\
5 / 1338 \%(13-68) \\
62 / 13446 \%(38-55)\end{array}$ & $\begin{array}{c}36 / 8045 \%(33-57) \\
35 / 6256 \%(43-69) \\
34 / 4576 \%(60-87) \\
6 / 1346 \%(19-75) \\
80 / 180^{\star} 44 \%(37-52)\end{array}$ & $\begin{array}{l}{ }^{6} \mathrm{Kitchen}, 1985 \\
{ }^{7} \mathrm{Yu}, 1986 \\
{ }^{5} \mathrm{Milligan}, 1984 \\
{ }^{8} \mathrm{Nwaesi}, 1987 \\
{ }^{9} \mathrm{Cooke}{ }^{\star} 1994 \text { and } \\
\text { personal communication }\end{array}$ \\
\hline $\begin{array}{l}\text { Ontario, Canada } \\
\text { Cleveland, USA } \\
\text { Maine, USA } \\
\text { Haifa, Israel } \\
\text { Northern region, UK } \\
\text { Holland }\end{array}$ & $\begin{array}{l}1982-87 \\
1982-88 \\
1982-92 \\
1982-86 \\
1983 \\
1983\end{array}$ & $\begin{array}{l}12 / 5522 \%(12-35) \\
3 / 378 \%(2-22) \\
31 / 114^{\star} \text { not includec } \\
0 / 19^{\star} \text { not included }\end{array}$ & $\begin{array}{l}49 / 11443 \%(34-52) \\
8 / 5116 \%(7-29) \\
\text { d in totals } \\
5 / 4012 \%(4-27) \\
2 / 1910 \%(1-33) \\
\text { in totals }\end{array}$ & $\begin{array}{c}109 / 17562 \%(55-70) \\
42 / 8052 \%(41-64) \\
57 / 10057 \%(47-67) \\
2 / 277 \%(0-24) \\
7 / 2232 \%(14-55) \\
7 / 4815 \%(6-28)\end{array}$ & $\begin{array}{c}152 / 22368 \%(62-74) \\
52 / 8263 \%(52-74) \\
62 / 9665 \%(54-74) \\
8 / 1942 \%(20-67) \\
13 / 2748 \%(29-68) \\
29 / 7738 \%(27-49)\end{array}$ & $\begin{array}{l}10 \text { Whyte, } 1993 \\
11 \text { Hack, } 1989 \\
12 \text { Philips, } 1995 \\
{ }^{13} \text { Weissman, } 1989 \\
14 \text { W Wariyar, } 1989 \text { a and b } \\
\text { 16Veerlove-Vanhorick, } \\
1988\end{array}$ \\
\hline $\begin{array}{l}\text { Vancouver, Canada } \\
\text { Oxford, UK } \\
\text { Copenhagen, Denmark } \\
\text { Tokyo, Japan } \\
\text { Scotland, UK } \\
\text { Leiden, Holland } \\
\text { Dusseldorf, Germany } \\
\text { North Carolina, USA } \\
\text { Minneapolis, USA } \\
\text { Cambridge, UK } \\
\text { Baltimore, USA } \\
\text { Detroit, USA } \\
\text { North Carolina, USA } \\
\text { Trent region, UK }\end{array}$ & $\begin{array}{l}1983-89 \\
1984-86 \\
1984-87 \\
1984-90 \\
1985 \\
1985-87 \\
1986 \\
1986-88 \\
1986-90 \\
1985-92 \\
1988-91 \\
1988-91 \\
1989-91 \\
1991-93\end{array}$ & $\begin{array}{l}9 / 3228 \%(14-47) \\
5 / 60^{\star \star} \text { not included } \\
3 / 743 \%(10-82) \\
0 / 60 \%(0-46) \\
0 / 20 \%(0-84) \\
12 / 3237 \%(21-56) \\
2 / 922 \%(3-60) \\
6 / 4015 \%(6-30) \\
2 / 287 \%(1-23) \\
0 / 210 \%(0-16) \\
1 / 373 \%(0-14)\end{array}$ & $\begin{array}{c}46 / 8752 \%(42-64) \\
\text { d in totals } \\
0 / 30 \%(0-71) \\
14 / 1593 \%(68-99) \\
1 / 214 \%(0-24) \\
3 / 475 \%(19-99) \\
0 / 30 \%(0-70) \\
1 / 1010 \%(0-44) \\
28 / 7537 \%(26-49) \\
13 / 2846 \%(27-66) \\
19 / 3456 \%(38-72) \\
13 / 4032 \%(19-50) \\
5 / 1146 \%(17-77) \\
27 / 9528 \%(20-39)\end{array}$ & $\begin{array}{c}88 / 14362 \%(54-70) \\
10 / 4522 \%(11-37) \\
7 / 887 \%(47-100) \\
17 / 2085 \%(62-97) \\
6 / 3219 \%(7-36) \\
7 / 1450 \%(23-77) \\
2 / 540 \%(5-85) \\
9 / 2536 \%(18-57) \\
54 / 9060 \%(50-70) \\
26 / 5547 \%(33-61) \\
31 / 3979 \%(63-90) \\
11 / 4425 \%(13-40) \\
14 / 2264 \%(41-83) \\
38 / 10436 \%(27-46)\end{array}$ & $\begin{array}{c}111 / 17065 \%(58-72) \\
32 / 6648 \%(36-61) \\
18 / 4045 \%(30-61) \\
21 / 2584 \%(64-96) \\
29 / 6148 \%(35-61) \\
6 / 1060 \%(26-88) \\
3 / 1718 \%(26-88) \\
24 / 3080 \%(61-92) \\
72 / 11364 \%(55-73) \\
43 / 8054 \%(42-65) \\
35 / 6256 \%(43-69) \\
18 / 2572 \%(51-88) \\
73 / 13255 \%(47-64)\end{array}$ & $\begin{array}{l}{ }^{17} \text { Synnes, } 1994 \\
{ }^{18} \mathrm{Johnson}, 1993 \\
{ }^{19} \text { Eg-Andersen, } 1989 \\
{ }^{20} \text { Nishida, 1993 } \\
{ }^{21} \text { Working group, } 1990 \\
{ }^{22} \text { Ruys, } 1989 \\
{ }^{21} \text { Working group, } 1990 \\
{ }^{23} \text { Wood, 1989 } \\
\text { 24 Ferrara, 1994 } \\
\text { Unpublished } \\
\text { 25 Allen, 1993 } \\
{ }^{26} \text { Holtrop, } 1994 \\
{ }^{27} \text { Katz, 1993 } \\
{ }^{28} \text { Bohin, 1995 }\end{array}$ \\
\hline $\begin{array}{l}\text { Totals }(\%) \\
95 \mathrm{CI} \text { of per cent }\end{array}$ & & $\begin{array}{l}59 / 375 \\
16 \%(12-19)\end{array}$ & $\begin{array}{l}289 / 834 \\
35 \%(31-38)\end{array}$ & $\begin{array}{l}661 / 1387 \\
48 \%(45-50)\end{array}$ & $\begin{array}{l}992 / 1735 \\
57 \%(55-60)\end{array}$ & \\
\hline
\end{tabular}

from large cohorts spanning a decade or more, but none of these reports is from geographical populations and the overall impression (table 1) is that the changes are not dramatic and are overshadowed by the differences between hospitals. My own view is that information which is as up to date as possible should be made available to parents and used as a basis for talking with them, and that they should be fully informed of the risk of serious handicap in the survivors. For this purpose I have summarised the published reports which give survival and neurological outcome by each week of gestational age for babies born since 1977 in tables $1-3$ and fig 1 . It should be emphasised to parents that these data are a crude outline, and that once the baby is born other factors will immediately influence the chance of intact survival. The predictions depend on the baby being born alive, as very few authors report the stillbirth rate at these low gestational ages. ${ }^{14}$ These factors include the condition of the baby at delivery, the race and sex of the child, and later on the presence or absence of a major intracranial lesion, severe lung disease, or retinopathy of prematurity.

New information regarding 'minor' problems such as school failure is published almost daily, although the total number of infants followed up is still remarkably small. As Escobar said: 'Our ability to assess and report the outcome of surviving very low birthweight infants has lagged behind our willingness to resuscitate them' ${ }^{29}$ The prospect of a normal survivor is only about one in 20 at 23 weeks, and at this gestation if the child lives it is more likely to be handicapped than not. At 24 weeks the normal and abnormal survivors are just about in balance, and after this time the odds are in favour of a normal survivor. Allen et al ${ }^{25}$ used similar data to argue that intensive care should be an optional choice for parents of children born at 23 and 24 weeks of gestation, but that intensive care should be offered to babies born at more than 25 weeks. So far society and the law have accepted non-treatment of handicapped newborns when the decision has been made with the knowledge that the child faced a very poor quality of life, although there are potential difficulties when extrapolation is made to the case of preterm infants at birth who are not certain to become brain damaged. In the case of Baby J, who was preterm with hydrocephalus, Lord Justice Taylor stated: 'I

Table 2 Summary of numbers of normal survivors/total survivors by gestational age, babies born late 1970s to early 1990s

\begin{tabular}{|c|c|c|c|c|c|c|}
\hline \multirow[b]{2}{*}{ Place } & \multirow{2}{*}{$\begin{array}{l}\text { Year of } \\
\text { birth }\end{array}$} & \multicolumn{4}{|c|}{ Gestational age (weeks) } & \multirow[b]{2}{*}{ Reference } \\
\hline & & 23 & 24 & 25 & 26 & \\
\hline $\begin{array}{l}\text { Queen's, Melbourne, Australia } \\
\text { Royal Women's, Melbourne, Australia } \\
\text { Liverpool, UK } \\
\text { Ontario, Canada } \\
\text { Northern region, UK } \\
\text { Vancouver, Canada } \\
\text { Oxford, UK } \\
\text { Copenhagen, Denmark } \\
\text { Minneapolis, USA } \\
\text { Cambridge, UK }\end{array}$ & $\begin{array}{l}1977-84 \\
1977-82 \\
1980-93 \\
1982-87 \\
1983 \\
1983-89 \\
1984-86 \\
1984-87 \\
1986-90 \\
1985-92\end{array}$ & $\begin{array}{l}1 / 2 \\
3 / 27 \\
6 / 12 \\
3 / 9\end{array}$ & $\begin{array}{c}11 / 13 \\
1 / 2 \\
22 / 84 \\
20 / 49 \\
1 / 1 \\
27 / 43 \\
1 / 5^{\star} \\
0 \\
20 / 28 \\
9 / 13\end{array}$ & $\begin{array}{l}3 / 11 \\
2 / 6 \\
48 / 134 \\
65 / 109 \\
3 / 6 \\
52 / 77 \\
0 / 9 \\
5 / 7 \\
38 / 54 \\
16 / 27\end{array}$ & $\begin{array}{c}26 / 35 \\
13 / 21 \\
50 / 73^{\star} \\
105 / 152 \\
8 / 12 \\
3 / 31 \\
16 / 18 \\
49 / 72 \\
28 / 43\end{array}$ & $\begin{array}{l}{ }^{7} \mathrm{Yu}, 1986 \\
{ }^{6} \mathrm{Kitchen}, 1985 \\
{ }^{9} \mathrm{Cooke} \text {, personal communication and *1994 } \\
{ }^{10} \mathrm{Whyte}, 1993 \\
{ }^{15} \mathrm{~W} \text { ariyar, } 1989 \\
{ }^{17} \text { Synnes } \text { et al, } 1994 \\
{ }^{18} \mathrm{Johnson}, 1993 \\
{ }^{19} \mathrm{Eg}-\text { Andersen, } 1989 \\
{ }^{24} \mathrm{Ferrara} \text {. } 1994 \\
\text { Unpublished }\end{array}$ \\
\hline $\begin{array}{l}\text { Totals (\%) } \\
95 \% \text { CI }\end{array}$ & & $\begin{array}{l}18 / 64 \\
28 \%(18-41)\end{array}$ & $\begin{array}{l}111 / 233 \\
48 \%(41-54)\end{array}$ & $\begin{array}{l}232 / 440 \\
53 \%(48-57)\end{array}$ & $\begin{array}{l}298 / 457 \\
65 \%(61-70)\end{array}$ & \\
\hline
\end{tabular}

^Not included in totals. 
Table 3 Summary of number of handicapped children/total survivors by gestational age, babies borm late 1970s to early 1990s

\begin{tabular}{|c|c|c|c|c|c|c|}
\hline \multirow[b]{2}{*}{ Place } & \multirow{2}{*}{$\begin{array}{l}\text { Year of } \\
\text { birth }\end{array}$} & \multicolumn{4}{|l|}{ Gestational age } & \multirow[b]{2}{*}{ Reference } \\
\hline & & 23 & 24 & 25 & 26 & \\
\hline \multirow{8}{*}{$\begin{array}{l}\text { Queen's, Melbourne, Australia } \\
\text { Royal Women's, Melbourne, } \\
\text { Australia } \\
\text { Ontario, Canada } \\
\text { Novia Scotia, Canada } \\
\text { Liverpool, UK } \\
\text { Haifa, Israel } \\
\text { Northern region, UK } \\
\text { Vancouver, Canada } \\
\text { Oxford, UK } \\
\text { Copenhagen, Denmark }\end{array}$} & $1977-84$ & $1 / 2(n=27)$ & $2 / 13(n=40)$ & $5 / 11(n=43)$ & $9 / 35(n=58)$ & ${ }^{7} \mathrm{Yu}, 1986$ \\
\hline & $\begin{array}{l}1977-82 \\
1979-82\end{array}$ & $0 / 1(n=7)$ & $\begin{array}{l}1 / 2(n=16) \\
3 / 8(n=23)\end{array}$ & $\begin{array}{l}3 / 6(n=32) \\
4 / 27(n=44)\end{array}$ & $\begin{array}{l}3 / 21(n=45) \\
3 / 27(n=45)\end{array}$ & $\begin{array}{l}{ }^{6} \text { Kitchen, } 1985 \\
{ }^{5} \text { Milligan, } 1984\end{array}$ \\
\hline & & & $0 / 1(n=10)$ & $3 / 5(n=13)$ & $0 / 6(n=13)$ & ${ }^{8}$ Nwaesi, 1987 \\
\hline & $1980-93$ & & $3 / 8(n=64)$ & $12 / 46(n=111)$ & $16 / 73(n=180)$ & ${ }^{9}$ Cooke, 1994 \\
\hline & $1982-86$ & & $2 / 5(n=40)$ & $1 / 2(n=27)$ & $2 / 8(n=19)$ & ${ }^{13} \mathrm{Weissman}, 1989$ \\
\hline & 1983 & & $0 / 1(n=19)$ & $2 / 6(n=23)$ & $2 / 12(n=27)$ & ${ }^{15}$ Wariyar, 1989 \\
\hline & $\begin{array}{l}1983-89 \\
1984-86\end{array}$ & $6 / 9(n=32)$ & $\begin{array}{r}16 / 43(n=87) \\
4 / 5(n=60)^{\star}\end{array}$ & $\begin{array}{c}25 / 77(n=143) \\
6 / 9(n=45)\end{array}$ & $12 / 31(n=66)$ & $\begin{array}{l}{ }^{17} \text { Synnes, } 1994 \\
18\end{array}$ \\
\hline & $1984-87$ & & & $2 / 7(n=8)$ & $2 / 18(n=40)$ & $\begin{array}{l}{ }^{19} \text { Eg-Andersen, } \\
1989\end{array}$ \\
\hline $\begin{array}{l}\text { Minneapolis, USA } \\
\text { Cambridge, UK } \\
\text { Leiden, Holland }\end{array}$ & $\begin{array}{l}1986-90 \\
1985-92 \\
1985-87\end{array}$ & $\begin{array}{l}7 / 12(n=32) \\
2 / 2(n=9)\end{array}$ & $\begin{array}{l}8 / 28(n=75) \\
3 / 13(n=28) \\
2 / 3(n=4)\end{array}$ & $\begin{array}{c}16 / 54(n=90) \\
8 / 27(n=55) \\
0 / 7(n=14)\end{array}$ & $\begin{array}{c}23 / 72(n=113) \\
10 / 43(n=80) \\
2 / 6(n=10)\end{array}$ & $\begin{array}{l}{ }^{24} \text { Ferrara, } 1994 \\
\text { Unpublished } \\
{ }^{22} \text { Ruys, } 1989\end{array}$ \\
\hline $\begin{array}{l}\text { Total }(n=) \\
{[\%] 95 \% \text { CI }}\end{array}$ & & $\begin{array}{l}16 / 26(n=107) \\
{[62 \%]: 41-80}\end{array}$ & $\begin{array}{l}48 / 125(n=406) \\
{[38 \%]: 30-47}\end{array}$ & $\begin{array}{l}87 / 284(n=648) \\
{[31 \%]: 25-36}\end{array}$ & $\begin{array}{l}84 / 352(n=696) \\
{[24 \%]: 20-28}\end{array}$ & \\
\hline
\end{tabular}

«Not included in totals.

consider that the correct approach is for the court to judge the quality of life the child would have to endure if given the treatment and decide whether in all circumstances such a life would be so afflicted as to be intolerable to the child. I say to that child because the test should not be whether the life would be tolerable to the decider. The test must be whether the child in question, if capable of exercising sound judgment, would consider the life tolerable'. ${ }^{30}$ In the same summing up he said: 'where the child is terminally ill the court will not require treatment to prolong life; but where, at the other extreme, the child is severely handicapped, although not intolerably so, and treatment for a discrete condition can enable life to continue for an appreciable period, albeit subject to that severe handicap, the treatment should be given'. Based on these considerations, if there has been no time for discussion with the parents the best course of action is to attempt to resuscitate all live born babies of 23 weeks gestation and above. It is reasonable not to attempt to resuscitate at 22 weeks, and in a case tested in a Scottish court, the judge ruled that it was not the duty of the doctor to resuscitate a non-viable infant. ${ }^{31}$

\section{Management at delivery}

Having spoken with the parents beforehand, the most senior paediatrician available should be present at the delivery and a second experienced pair of hands is essential. Ideally a plan of action will have been talked through with the parents and the midwife. It is wise to

Figure 1 Histogram showing percentage of survivors at each gestational age between 23 and 26 weels. Blocks are and 26 weels. Blocks are are normal or with minor handicap, and those with a major neurodevelopmental handicap. emphasise that the plan may have to be changed due to unexpected circumstances and that if possible these changes will be discussed at the time, or at least as soon as the emergency allows. The situation where the baby is larger and more vigorous or smaller than expected should be planned for; weighing the baby at delivery can help decision making as survival is still very rare below $500 \mathrm{~g}$. Even if the parents have requested that everything be done things may not go according to plan and a second experienced person can prove invaluable in supporting and explaining events which will live long in the parents' minds. Two different cases illustrate the point. The first was a 23 week gestational age baby whose parents were desperate for everything to be done. However, at delivery the child was floppy, apnoeic, and pale with a heart rate of 20 beats a minute. He responded poorly to resuscitative efforts, including blood transfusion, external cardiac massage, and bicarbonate treatment. At 25 minutes of age, still in the delivery room, he had just begun to gasp but the $\mathrm{pH}$ was only 6.7. I was able to spend much of the time at the parents' bedside explaining events while they could see full resuscitation continuing. By 25 minutes his prospect of normal survival, always low, was zero. We agreed that to transfer him to the neonatal intensive care unit would be futile and he was given to his parents to die in their arms. Their state of mind months later was vastly different from that of a couple who had requested transfer from another hospital in order to give their baby the best chance, but whose baby girl had delivered rapidly after arrival without time for counselling or a paediatrician to be present. Her parents felt bitter and angry for several years after her death following 48 hours of intensive care and chose to deliver their next child at another hospital.

\section{Is full cardiopulmonary resuscitation appropriate for infants of marginal viability?}

The brief case histories outlined serve as a reminder that the outcome after full cardiopulmonary resuscitation (CPR) in the delivery suite for very preterm infants is appalling. 
Three of five infants of less than 28 weeks gestation who were given adrenaline and bicarbonate during initial resuscitation in Manchester died and both survivors were handicapped. ${ }^{32}$ All the very low birthweight infants who required more than one resuscitative attempt in Oklahoma died. ${ }^{33}$ There were only two normal survivors among the 11 very low birthweight infants who were given full CPR with drugs, external cardiac massage, and adrenaline in Cambridge during the years 1989-93. All six infants of birthweight $<750 \mathrm{~g}$ who were given full CPR in Ottowa during 1989-92 died, ${ }^{34}$ and there were no survivors either after more than 30 minutes of CPR in a study of very low birthweight infants. ${ }^{35}$ There is some evidence that the commonly recommended intravenous dose of adrenaline (10 $\mu \mathrm{cg} / \mathrm{kg})$ is inadequate, although it seems unlikely that adoption of the larger dose of 250 $\mu \mathrm{cg} / \mathrm{kg}$ will alter these poor results. More accurate information is needed on this topic, and may be forthcoming from the Confidential Enquiry into Stillbirths and Deaths in Infancy or the current UK (EPICure) study of very premature infants.

\section{Ethics of non-intervention, rights of the baby and the parents}

Before using this information for counselling, paediatricians need to ponder for themselves it is always easy to agree to try to save life but what line of action should they take if the parents refuse resuscitation at 26 weeks? What are the rights of the fetus at this gestation, who has an evens chance of intact survival? In recent years the courts have ascribed increasing rights to the fetus, even to requiring caesarean section against the mother's wishes. ${ }^{36}$ What should the neonatologist do if, having agreed not to resuscitate at 24 weeks, the baby is born active, with a cry and a good heart rate? Alternatively, if the parents want everything done are they prepared to use full CPR in infants of marginal viability given the poor results? Parents might choose options in their own best interests rather than the child's, trying to avoid a poor outcome at all costs, but overriding their wishes will lead to conflict and affect the child's quality of life if they reject him/her.

\section{Aftercare and continued counselling}

Prior frank discussion and provision of accurate information can only help later if a brain injury, short gut, or severe lung disease worsens the prognosis. Fortunately, most deaths occur rapidly but the long 'tail' hides much misery and considerable costs, both emotional and financial.

\section{Conclusion}

The management of delivery at 23-26 weeks of gestation involves difficult choices for both parents and perinatal physicians. The current state of knowledge permits only a crude assessment of prognosis, and is sufficiently incomplete to mean that access to intensive care should not be denied these infants. I consider that it is reasonable to offer not to resuscitate babies of 23 and 24 weeks gestational age, and to execute this plan if the parents agree and the baby is born in poor condition. I would try to discourage parents of a fetus who was to be delivered at 22 weeks gestation from seeking active treatment, and I would try to encourage them at 25 and 26 weeks, although I would make it clear that I was prepared to withdraw treatment later if the likelihood of severe neurological disability became more than $90 \%$. There are those who will feel that to follow this course of action will inhibit progress, but in view of the burden of care which handicapped infants place on their families and the distress caused by death after months of intensive care, it seems essential to have the parents' informed consent before embarking on treatment, and their cooperation during it. Full CPR may be inappropriate for very low birthweight infants but more information is urgently needed. Management could be helped if in the future outcomes were reported by days of gestation, the sex of the infant was always included in research reports, and more attention was paid to describing the initial condition, antenatal treatment withdrawal of care policies and events in the delivery room.

I thank Dr Alun Elias-Jones for help with the legal aspects of this article, and my junior staff for constructive criticism.

1 C vs $S$ [1988] QB 135; [1987] 1 All ER 1230

2 Dunn PM, Stirrat GM. Capable of being born alive? Lancet 1984; i: 553-5.

3 Annas GJ Asking the courts to set the standard of emergency care - the case of baby K. N Engl f Med 1994; 350 $1542-5$

4 The Times July 1995, page 3, column $\mathrm{B}$.

5 Milligan JE, Shennan AT, Hoskins EM. Perinatal intensive care: where and how to draw the line. Am $\mathcal{F}$ Obstet Gynecol 1984; 148: 499-503.

6 Kitchen W, Ford GW, Doyle LW, Rickards AL, Lissenden JV, Pepperell RJ, et al. Caesarean section or vaginal delivery at 24 to 28 weeks gestation: comparison of survival and neonatal and two-year morbidity. Obstet Gynaecol 1985; 66: 149-57.

7 Yu VYH, Loke HL, Bajuk B, Szymonowicz W, Orgill AA, Astbury J. Prognosis for infants born at 23-28 weeks gestation. $B M \mathcal{A}$ 1986; 293: 1200-3.

8 Nwaesi CG, Young DC, Byrne JM, Vincer MJ, Sampson D, Evans JR, et al. Preterm birth at 23 to 26 weeks' gestation: is active obstetric management justified? $A m \boldsymbol{f}$ Obstet is active obstetric manage

9 Cooke RWI. Factors affecting survival and outcome at 3 years in extremely preterm infants. Arch Dis Child 1994; 71: F28-F31.

10 Whyte HE, Fitzhardinge PM, Shennan AT, Lennox K Smith L, Lacy J. Extreme immaturity: outcome of 568 pregnancies of 23-26 weeks gestation. Obstet Gynaecol 1993; 82: 1-7.

11 Hack M, Fanaroff A. Outcomes of extremely low birth weight infants between 1982 and 1989. N Engl f Med 1989; 321: 1642-7.

12 Philip AGS. Neonatal mortality rate: is further improvement still possible? F Pediatr 1995; 126: 427-33.

13 Weissman A, Jakobi P, Blazer S, Avrahami R, Zimmer EZ. Survival and long term outcome of infants delivered at 24 to 28 weeks gestation by method of delivery and fetal preto 28 weeks gestation by method of delive

14 Wariyar U, Richmond S, Hey E. Pregnancy outcome at 24-31 weeks gestation: mortality. Arch Dis Child 1989; 64: $670-7$

15 Wariyar U,Richmond S, Hey E. 1989 pregnancy outcome at 24-31 weeks gestation: neonatal survivors. Arch Dis Child 64: 678-86.

16 Veerlove-Vanhorick SP, Verwey RA, Ebeling MCA, Brand $\mathrm{R}$, Ruys $\mathrm{JH}$. Mortality in very preterm and very low birthweight infants according to place of birth and level of care. Pediatrics 1988; 82: 404-11.

17 Synnes AR, Ling EWY, Whitfield MF, Mackinnon $M$, Lopes L, Wong G, et al. Perinatal outcomes of a large cohort of extremely low gestational age infants (twentythree to twenty-eight completed weeks of gestation) three to twenty-eight complet

18 Johnson A, Townshend P, Yudkin P, Bull D, Wilkinson AR. Functional abilities at age 4 years of children born before 29 weeks gestation. BMF 1993; 306: 1715-17. 
19 Eg-Andersen G. Prediction of outcome in 164 infants born after 24 to 28 weeks gestation. Acta Paediatrica Scand 1989; 360: 56-61.

20 Nishida $H$. Outcome of infants born preterm, with special emphasis on extremely low birthweight infants. Ballière's Clin Obstet Gynaecol 1993; 7: 611-31.

21 Working group on the very low birthweight infant. European Community Study of outcome of pregnancy between 22 and 28 weeks' gestation. Lancet 1990; 336: $782-4$.

22 Ruys JH, Veerlove-Vanhorick SP, Den Ouden AL. The viability of the preterm infant. Eur $\mathcal{F}$ Obstet Gynaecol Reprod Biol of the preterm

23 Wood B, Katz V, Bose C, Goolsby R, Kraybill E. Survival and morbidity of extremely premature infants based on obstetric assessment of gestational age. Obstet Gynaecol obstetric assessment

24 Ferrara TB, Hoekstra RE, Couser RJ, Gaziano EP, Calvin SE, Payne NR, et al. Survival and follow up of infants born at 23 to 26 weeks of gestational age: effects of surfactant therapy. $\mathcal{F}$ Pediatr 1994; 124: 119-24.

25 Allen MC, Donohue PK, Dusman AE. The limit of viability - neonatal outcome of infants born at 22-25 weeks gestation. N Engl f Med 1993; 329: 1597-601.

26 Holtrop PC, Ertzbischoff LM, Roberts CL, Batton DG,
Lorenz RP. Survival and short term outcome in newborns of 23 to 25 weeks gestation. Am ₹ Obstet Gynecol 1994; 170: 1266-70.

27 Katz VL, Bose CL.Improving survival of the very premature infant. F Perinatol 1993; 13: 261-5.

28 Bohin S, Draper ES, Field DJ. The impact of extremely immature infants on neonatal services. Arch Dis Child 1996; 74: F110-13.

29 Escobar GJ, Littenberg B, Pettiti DB. Outcome among surviving very low birthweight infants: a meta-analysis. Arch Dis Child 1991; 66: 204-11.

$30 \mathrm{Re} J$ (a minor) [1990] 3 All ER 930, CA 2 WLR 140.

31 Brahams D. No obligation to resuscitate a non-viable infant. Lancet 1988; i: 1176 .

32 Sims DG, Heal CA, Bartle SM. Use of adrenaline and atropine in neonatal resuscitation Arch Dis Child 1994; 70:

33 Sood S, Giacoia P. Cardiopulmonary resuscitation in very low birthweight infants. Am $\mathcal{F}$ Perinatol 1992; 9: 130-3.

34 Davis DJ How aggressive should delivery room CRP be for ELBW neonates? Pediatrics 1993; 92: 447-50.

35 Innes PA, Summers LA, Boyd IM, Molyneux EM. Audit of pediatric CPR. Arch Dis Child 1993; 68: 487-91. 